\title{
Rethinking Justice
}

\author{
Mark Goodale
}

\author{
Man or Monster? The Trial of a Khmer Rouge Torturer \\ by Alexander Laban Hinton \\ Duke University Press, 360 pp., \$28.95.
}

\section{The Justice Facade: Trials of Transition in Cambodia by Alexander Laban Hinton \\ Oxford University Press, 282 pp., \$32.95.}

"To the attention of Uncle Peng. Kill them all. 30 May 1978." -Note affixed to a list of new prisoners by the commandant of S-21, the Khmer Rouge's most notorious interrogation and execution center. ${ }^{1}$

$\mathrm{I}$ N NOVEMBER 1984, I had just turned 17 years old. I was at the beginning of my senior year in high school, an immature kid growing up in a seaside town on California's Santa Monica Bay. I was an indifferent student and my limited knowledge of the world had been shaped during the conservative social climate of the Reagan presidency. One weekend that November, my father decided to take me to see a newly released film at the local cineplex. As we sat down to watch The Killing Fields, I knew little about Cambodia other than that it was a country in Southeast Asia and that it shared a border with Vietnam. ${ }^{2}$

The poignant true story of the friendship between the New York Times reporter Sydney Schanberg and the Cambodian journalist and interpreter Dith Pran certainly left a lasting impression. But it was the unsparing depiction of the genocidal violence perpetrated by the Khmer Rouge that made viewing the film a life-changing experience. I watched people get bludgeoned to death, shot in the head in summary executions, and crudely suffocated with plastic bags. Indeed, even now, despite never rewatching the film, I am still haunted by a scene in which corpses are scattered across a rural reeducation camp, mouths agape inside plastic bags that have been pulled over their heads.

Many years later, this early cinematic encounter with the Cambodian genocide would form part of the background thoughts and emotions that channeled my scientific interests toward the anthropological study of human rights. Unlike Alexander Hinton, author of the two books under consideration here, I was not able to concentrate my work around the unimaginably complicated tragedies labeled genocide. Instead, I have spent my career studying the more subtle ways in which human rights are taken up as a language of political resistance and cultural empowerment. ${ }^{3}$ Despite the first stirrings of outrage on that afternoon in 1984, in the end I did not become, like Hinton, a genocide scholar, willing to devote a life of research, writing, and moral introspection to the darkest corners of the human experience.

$\mathrm{W}$

ITH THE PUbLication of Man or Monster? The Trial of a Khmer Rouge Torturer in 2016 and The Justice Facade: Trials of Transition in Cambodia in 2018, Hinton completed an unprecedented trilogy that began with Why Did They Kill? Cambodia in the Shadow of Genocide in 2004. These three works represent a sustained effort to understand and explain genocide. As an anthropologist, Hinton has pursued this 25-year task from the inside out, conducting long-term ethnographic research in Cambodia informed by his deep knowledge of the country's history, his facility with the Khmer language, and his willingness to humanize those who perpetrated the Cambodian genocide, from the low-level cadres who carried out the mass killings to the high-ranking officials who sealed the fate of hundreds of thousands. Hinton's focus on the killers as well as the victims serves the theme of his research, which is an attempt to explain the "paradox of perpetration: how can a human commit inhuman acts?"

In seeking to make sense of this enigma, Hinton rejects the two most common explanations. The first appeals to the cliché that those who commit atrocities are monsters whose barbarism is the result of a "lower, more animal-like state of [human] development." ${ }^{5}$ As an illustration, Hinton quotes from the visitors' book at S-21, the Khmer Rouge interrogation and execution center in Phnom Penh also known as Tuol Sleng. This former high school was converted by the Khmer Rouge into a factory for systematic torture, forced medical experimentation, and mass killing. Visitors to what is now the Tuol Sleng Genocide Museum 
are invited to record their thoughts after having toured the grounds where an estimated 20,000 men, women, and children disappeared. Indeed, one of the distinguishing characteristics of S-21 was its dark simplicity. The facility existed solely to extract information from the perceived enemies of the Khmer Rouge's agrarian revolution; prisoners were kept alive only for this purpose. Otherwise, their fates had already been decided before they arrived. As Duch, the commandant of S-21 whose 2009 trial is at the center of Man or Monster?, explained in court, "the detainees were 'treated as dead people' whose end had been briefly delayed."

International visitors to the Tuol Sleng Genocide Museum respond to the photographic and artifactual evidence with expressions that keep the Cambodian genocide confined to a parallel universe of the unspeakable and unknowable: "No words," "Why?" "Indescribable," "Words fail me," or "Speechless." Some visitors attempt to provide an answer by describing it in terms of monstrosity: "inhumanity," "barbarities," "cruelty," "cretins," "horrors," or "evil." "People who can do this to other people," a woman from the Netherlands wrote, "are no more than monsters!"”

The second explanation for genocide is more recent, and rooted in modern social psychology and theories of deviance. The capacity to commit genocidal violence is explained as a collective and extreme deviance from a baseline psychological norm. This explanation often focuses on the extent to which torturers can experience sexual gratification from inflicting pain and suffering on others. ${ }^{8}$

On Hinton's view, both explanations naturalize the violence of mass atrocity. Since the presence of both monsters and deviants is seen as an unfortunate, if inevitable, fact of human existence, it is only natural-given a particular set of political, economic, and historical circumstances-that they will be more than willing to smash a prisoner in the back of the head with an axe, repeatedly apply high-voltage electric shocks, or kill the children of prisoners by bashing their heads against the trunks of trees.'

As a radical alternative to the monster and deviance explanations, Hinton argues that genocide is the rare and tragic expression of the "banality of everyday thought." 10 This adaptation of Hannah Arendt's notion of the banality of evil finds the potential for genocide latent within "the everyday ways we simplify and categorize the world in order to navigate complexity."11 According to Hinton, everyday thought demands constant exclusions and inclusions, along with the categorizing through which simplified yet usable meanings are derived from the endless variety of experience and diversity. This banality of everyday thought is not random in nature, but organized in political, cultural, and ideological terms. Given a set of extraordinary factors, described by other genocide scholars as predictable "stages of genocide,"” the organization of such everyday thought can metastasize into genocidal violence. This can be seen in the development and acceptance of categories such as "enemy of the people," "inferior race," and inyenzi. ${ }^{13}$

The banality of everyday thought remains Hinton's more general contribution to genocide scholarship, and both Man or Monster? and The Justice Facade represent unexpected and illuminating applications of the idea. Instead of taking up the question of the Cambodian genocide itself, a topic addressed in his first book, ${ }^{14}$ Hinton refocuses on how popular depictions of the genocide have relied on their own forms of categorical reductionism, a process that he refers to as effacement.

$\mathrm{I}$ N Man or Monster? Hinton follows the 2009 trial of Duch, the commandant of S-21. The book is neither a study of Duch himself, nor his crimes as a Khmer Rouge leader. Instead it examines the ways in which Duch was portrayed during and after the trial: a genocidal Khmer Rouge monster, a guilt-free and dutiful soldier of the revolution simply following orders, a bookish former mathematics teacher with a punctilious eye for detail, and a Cambodian patriot whose excesses were committed to liberate the country from the shackles of imperialism and Western colonialism. According to Hinton, this complex image of Duch was a contributing factor to the controversial outcome of his trial by the Extraordinary Chambers in the Courts of Cambodia. In 2010, Duch was sentenced to 35 years in prison, reduced by 11 years for time served and a further 5 years for what the court found to be illegal detention, leaving an actual sentence of 19 years. Two years later, the Cambodian Supreme Court, most likely bowing to national political pressure ${ }^{15}$ overturned this judgment and sentenced the 70-year-old Duch to life in prison. It was the first such sentencing of a high-ranking Khmer Rouge official, and it came, notably, more than 30 years after the end of the genocide. Hinton, who was in the courtroom for the final verdict, described the defendant's reaction:

Duch perfunctorily raises his hands to sampeah the judges, then leaves the court, detention guards behind and before him. He doesn't look at the audience as he passes the glass wall. He looks as if he might cry. ${ }^{16}$

The Justice Facade is also based on research conducted during and after the Khmer Rouge tribunal. Rather than focusing on the ways in which Duch or the Khmer Rouge were portrayed, Hinton turns his attention to the banalities of everyday thought at work through legal and political institutions. The tribunal to try the Khmer Rouge perpetrators, he argues, was only possible after decades of transnational human rights activism, international coercion, and the development within Cambodia of nongovernmental organizations (NGOs) whose work was 
funded and directed, at least in part, by international partners. The process that led to the Khmer Rouge tribunal was as much a didactic as a political one. Cambodians, now decades removed but still collectively scarred by the horrors of genocide, had to be taught how to demand justice.

This course of national political and moral education, Hinton argues, required the diffusion-often by means of pamphlets and picture books produced by NGOs such as the Khmer Institute of Democracy-of a specific set of liberal democratic norms grounded in assumptions of teleological transformation, progressivism, universalism, essentialism, and globalism. ${ }^{17}$ Beginning in the late $1980 \mathrm{~s}$ through a series of initial experiments in Argentina and Chile, the practice of transitional justice was successfully professionalized by international and transnational organizations. After protracted social conflict, the implementation of national criminal tribunals along with truth and reconciliation commissions came to be seen as a necessary precondition to unleash what Kathryn Sikkink termed a justice cascade-the spread of democracy and peaceful social relations through the enforcement of international human rights norms at the national level. ${ }^{18}$

As the title of Hinton's book suggests, his research led him to question the notion of the justice cascade. His study takes direct aim at Sikkink's body of work and at the activist organizations that drive the global transitional justice movement. Instead of a harmonious cascade, Hinton finds that, in practice, transitional justice functions as a set of superficial judicial and political mechanisms masking much more than they reveal. The chapters of The Justice Facade are therefore intended to unmask what the Khmer Rouge tribunal obscured, from the diverse ways people experienced the violence and its aftermath to the cultural forms that mediated these experiences. In particular, he finds that local religious and artistic practices were much more effective in helping people cope with the legacies of the genocide than the formal processes of justice-a word, Hinton notes, that is almost impossible to translate into Khmer. ${ }^{19}$

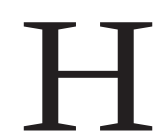

INTON'S TWO vOLUMES - and the wider trilogy that they conclude-represent outstanding ethnographic research on the Cambodian genocide. Even so, his work leaves readers with alternatives that offer little solace. Hinton's response to the tragic implications of everyday thinking, which he develops briefly at the end of Man or Monster?, is to suggest that we be more willing to "think critically and remain open to difference and the real-world complexities that we are inclined ... to pare down, edit, and redact." ${ }^{20}$ His solution to the problems arising from transitional justice is similarly modest: be more open to alternative approaches to social reckoning, especially those rooted in local forms of achieving closure, even if these demand forgiveness, forgetting, and even collective silence. ${ }^{21}$
Yet it is not these prescriptions that leave the most lasting impression. It is hard to shake the sense that after all the critical scholarship and unpacking of unsatisfactory theoretical categories, darker and still unexamined realities remain. In a section on the torture practices at S-21, Hinton mentions something, almost in passing, that offers a chilling window into these darker realities. Duch, the commandant of S-21, insisted on adherence to a set of rules and instructions for torture. Over time he found it was necessary to include a formal addendum to what came to be known as the torture manual. The problem? Young Khmer Rouge interrogators were taking such sadistic pleasure in their work that Duch felt compelled to point out that torture "is not done for fun" or simply to "let off steam."22

Mark Goodale is Professor of Cultural and Social Anthropology and Director of the Laboratory of Cultural and Social Anthropology at the University of Lausanne.

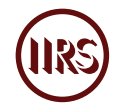

1. Alexander Hinton, Man or Monster? The Trial of a Khmer Rouge Torturer (Durham: Duke University Press, 2016), 66.

2. I knew the latter only because of its place in Apocalypse Now-a hugely popular film among my friends, one we watched repeatedly-in which Captain Willard crosses into Cambodia to confront and eventually assassinate the renegade US Army officer Colonel Kurtz.

3. See, e.g., Mark Goodale, Dilemmas of Modernity: Bolivian Encounters with Law and Liberalism (Stanford: Stanford University Press, 2008).

4. Hinton, Man or Monster?, 29.

5. Hinton, Man or Monster?, 30.

6. Hinton, Man or Monster?, 64. The extent of this dark simplicity is also marked by the fact that fewer than 15 people out of the estimated 20,000 who entered are believed to have survived S-21. Some who perished at S-21 did so because they were in the wrong place at the wrong time. As Hinton explains, a number of vacationing Westerners were swept into the buzz saw of S-21, including a handful of happy-go-lucky young sailors who allowed their boats to drift into Cambodian waters, where they were captured by Khmer Rouge navy patrols. These foreigners were taken immediately to S-21, where they were tortured over months, forced to sign confessions admitting to imaginary intelligence activities against the Khmer Rouge's Democratic Kampuchea, and then killed, after which their bodies were "'burned to ash' in car tires so that 'nothing would remain." Hinton, Man or Monster?, 166.

7. Hinton, Man or Monster?, 29.

8. Hinton, Man or Monster?, 30. 
9. All methods used by the Khmer Rouge, as described in Man or Monster?

10. See both Man or Monster? and Alexander Hinton, The Justice Facade: Trials of Transition in Cambodia (Oxford: Oxford University Press, 2018).

11. Hinton, Man or Monster?, 31.

12. See Gregory Stanton, "The Ten Stages of Genocide," The Genocide Education Project (1998). Stanton originally presented an earlier form, "The Eight Stages of Genocide," as a briefing paper to the US State Department in 1996.

13. This is the Kinyarwanda word for "cockroach," used by Hutus to categorize Tutsis before and during the Rwandan genocide of 1994.

14. Alexander Hinton, Why Did They Kill? Cambodia in the Shadow of Genocide (Berkeley, CA: University of California, 2005).
15. Hinton suggests that the 2012 Cambodian Supreme Court decision was the result of pressure applied by the government of Prime Minister Hun Sen, whose ruling Cambodian People's Party contained many former dissident Khmer Rouge cadres, after having overthrown Pol Pot's regime in 1979.

16. Hinton, Man or Monster?, 257.

17. Hinton, The Justice Facade, 10-18.

18. Kathryn Sikkink, The Justice Cascade: How Human Rights Prosecutions Are Changing World Politics (New York: W. W. Norton \& Co., 2011).

19. Hinton, The Justice Facade, 247.

20. Hinton, Man or Monster?, 295.

21. Hinton, The Justice Facade, 249.

22. Hinton, Man or Monster?, 146. 